\title{
Potential threats posed by a translocated crayfish: the case of Cherax destructor in coastal drainages of New South Wales, Australia
}

\author{
Jason Coughran and Garry Daly
}

\begin{abstract}
The yabby, Cherax destructor, is endemic to inland waterways of south-eastern Australia. However, as a result of aquaculture feral populations have become established outside its natural range, within and outside of Australia. In recent years, numerous translocated populations have been recorded from coastal drainages in New South Wales, where a sizeable diversity of endemic coastal crayfishes occur. Translocated yabbies represent a potential threat to indigenous fauna in the waterways of eastern New South Wales, and in this paper we outline the habitats and biota that may be at risk. We discuss several key concerns regarding this translocated crayfish, including: the probable pathways of introduction; its propensity to spread; potential competition and predation threats; pathogen concerns; and potential impacts at the habitat and ecosystem level.
\end{abstract}

\section{INTRODUCTION}

The yabby, Cherax destructor, is the most widely distributed freshwater crayfish in Australia, with a natural range that extends across several inland catchments west of the Great Dividing Range (Sokol, 1988). However, it has been translocated to other parts of the continent including Western Australia, Tasmania and, more recently, coastal catchments in New South Wales (NSW) (Austin, 1985; Elvey et al., 1996; Horwitz, 1990; Horwitz \& Knott, 1995; Coughran et al., 2009). Since the initial report of translocated populations of $C$. destructor in eastern NSW (Coughran et al., 2009), several additional populations have been recorded (McCormack \& Daly, unpublished data). The sudden occurrence of this translocated crayfish species in virtually all coastal drainage systems in NSW is of great concern to the protection and management of the indigenous fauna of these waterways. In this paper we outline the severity of the potential threat involved.

The aquatic ecosystems of NSW are most conspicuously defined by the Great Dividing Range, which divides the State's waterways into inland and coastal draining systems. Inland waterways are characterized by a low diversity of relatively widespread aquatic species, while the coastal drainages support a much richer diversity of species with comparatively small distributions. This difference is highlighted by the crayfish fauna of the state. Apart from a handful of species that occur in the upper headwaters along the Great Dividing Range, the major inland waterways are dominated by two species: the widespread yabby (Cherax destructor) and the River Murray Crayfish (Euastacus armatus). In contrast, the coastal waterways of NSW support more than 40 species from five genera (Table 1).

\section{Probable pathways.}

The probable pathways of translocated Cherax destructor in eastern drainages (i.e. aquarium release, use of bait yabbies in fishing, deliberate stocking as a food resource, etc) are all still present. Regrettably, the Australian Crayfish Project surveys have recorded further translocated populations of this species since the paper by Coughran et al. (2009) was published, and it has now been recorded in additional coastal drainages of NSW (an update listing the site details of these additional translocated populations will be published in due course; McCormack, pers. comm.). 
Table 1. The coastal drainages of New South Wales support more than 40 species of freshwater crayfish, most of which are endemic to coastal drainages. These crayfish are listed as 'restricted' if their estimated distribution is $<10,000 \mathrm{~km} 2$, and as 'highly restricted' if their estimated distribution is $<1,000 \mathrm{~km} 2$. Current IUCN Red List conservation classifications are provided where available

\begin{tabular}{|c|c|c|c|}
\hline \multicolumn{2}{|c|}{ Coastal Endemic } & Distribution Range & Conservation Status (IUCN) \\
\hline Cherax cuspidatus & yes & not restricted & Least Concern \\
\hline Cherax leckii & yes & highly restricted & Critically Endangered \\
\hline Cherax setosus & yes & restricted & $\mathrm{n} / \mathrm{a}$ \\
\hline Engaeus cymus & no & not restricted & Least Concern \\
\hline Engaeus orientalis & no & restricted & Least Concern \\
\hline Euastacus australasiensis & yes & not restricted & Least Concern \\
\hline Euastacus bidawalus & yes & restricted & Endangered \\
\hline Euastacus brachythorax & yes & restricted & Endangered \\
\hline Euastacus clarkae & yes & highly restricted & Critically Endangered \\
\hline Euastacus claytoni & no & restricted & Endangered \\
\hline Euastacus crassus & no & restricted & Endangered \\
\hline Euastacus dalagarbe & yes & highly restricted & Critically Endangered \\
\hline Euastacus dangadi & yes & restricted & Least Concern \\
\hline Euastacus dharawalus & yes & highly restricted & Critically Endangered \\
\hline Euastacus gamilaroi & no & highly restricted & Critically Endangered \\
\hline Euastacus girurmulayn & yes & highly restricted & Critically Endangered \\
\hline Euastacus gumar & yes & highly restricted & Endangered \\
\hline Euastacus guruhgi & yes & highly restricted & Critically Endangered \\
\hline Euastacus guwinus & yes & highly restricted & Critically Endangered \\
\hline Euastacus hirsutus & yes & restricted & Endangered \\
\hline Euastacus jagabar & yes & highly restricted & Critically Endangered \\
\hline Euastacus maccai & no & restricted & Endangered \\
\hline Euastacus mirangudjin & yes & highly restricted & Critically Endangered \\
\hline Euastacus morgani & yes & highly restricted & $\mathrm{n} / \mathrm{a}$ \\
\hline Euastacus neohirsutus & yes & restricted & Least Concern \\
\hline Euastacus pilosus & yes & highly restricted & Endangered \\
\hline Euastacus polysetosus & yes & highly restricted & Endangered \\
\hline Euastacus reductus & yes & restricted & Least Concern \\
\hline Euastacus rieki & no & restricted & Endangered \\
\hline Euastacus simplex & yes & not restricted & Vulnerable \\
\hline Euastacus spinichelatus & yes & highly restricted & Endangered \\
\hline Euastacus spinifer & no & not restricted & Least Concern \\
\hline Euastacus sulcatus & no & restricted & Vulnerable \\
\hline Euastacus suttoni & no & not restricted & Vulnerable \\
\hline Euastacus valentulus & yes & not restricted & Least Concern \\
\hline Euastacus yanga & yes & not restricted & Least Concern \\
\hline Euastacus sp. 1 & yes & highly restricted & $\mathrm{n} / \mathrm{a}$ \\
\hline Gramastacus sp. 1 & yes & highly restricted & $\mathrm{n} / \mathrm{a}$ \\
\hline Gramastacus sp. 2 & yes & highly restricted & $\mathrm{n} / \mathrm{a}$ \\
\hline Tenuibranchiurus sp. 1 & yes & highly restricted & $\mathrm{n} / \mathrm{a}$ \\
\hline Tenuibranchiurus sp. 2 & yes & highly restricted & $\mathrm{n} / \mathrm{a}$ \\
\hline
\end{tabular}


The threat of further introductions of this species in NSW is real, and in the absence of education programs or mechanisms to reduce the various introduction pathways, it is most likely that the species will continue to become established in waterways throughout all coastal drainages.

\section{Propensity to spread.}

Cherax destructor has a high propensity to spread and colonize new sites. The species is known to leave the water and travel overland considerable distances, and in some cases en masse, to colonize new habitats (Olszewski, 1980; Barnham \& Barker, 2009). It is environmentally tolerant and able to withstand extreme physicochemical conditions (Beatty et al. 2005), enabling it to occupy temporary habitats. Moreover, it is highly fecund and capable of continual spawning when conditions are suitable, advantageous traits for the rapid colonization of new areas (Beatty et al., 2005). The species can persist in a variety of water bodies, including temporary puddles, and may impact on a wide range of lentic and lotic species in coastal NSW. For example, in the Newcastle region ${ }^{1}$ it has recently been found in forestry dams, creeks, drains and, at one site, in a vehicle rut (McCormack \& Coughran, 2011).

\section{Competition threats and species displace- ment.}

Because of their superior biological attributes, translocated $C$. destructor have the potential to rapidly out-compete endemic crayfish species (Coughran et al., 2009). The population at Fitzroy Falls, for example, appears to be rapidly displacing an endemic crayfish, Euastacus dharawalus, which is now considered Critically Endangered (IUCN, 2011, Coughran and Furse, 2010; Furse \& Coughran, 2011a, b, c). The Australian Crayfish Project has been undertaking targeted surveys for $E$.

\footnotetext{
${ }^{1}$ It is worth noting that there is an endemic crayfish, C. setosus, restricted to this coastal area that could be threatened by reproductive interference from the translocated $C$. destructor (McCormack \& Coughran, 2011). Studies have shown that when crossed, the two species produce sterile, all male offspring (Lawrence et al., 1998, 2000).
}

dharawalus in recent years. When the situation at Fitzroy Falls was first brought to attention, a proposal was developed for continued and more specific population research on this species. However, relevant stakeholder agencies did not fund the initiative, on the basis that the issue was not of sufficiently high priority (McCormack, pers. comm.). The situation at Fitzroy Falls has the potential to cause the extinction of the iconic native crayfish that is only known from that site, and similar situations could be occurring elsewhere in coastal NSW.

The potential threat is not simply a matter of resource competition. Overseas studies have found inter-specific interactions can influence species replacements in crayfishes through a complex range of processes, involving factors such as reproductive interference, aggressive dominance, differential susceptibility to predation, habitat availability and quality, disturbance, health status, growth, and spatial and temporal access to food and shelter resources (Rabeni, 1985; Capelli \& Munjal, 1982; Butler \& Stein, 1985; Lodge et al., 1986; Söderbäck, 1991; Mather \& Stein, 1993; Garvey et al., 1994; Hill \& Lodge, 1994).

\section{Predation threats.}

The premeditated stalking and hunting for live prey, including frogs, tadpoles and fish, is a known feeding behaviour of yabbies generally (Bradsell et al., 2002; Hawking et al., 2009; Merrick, 1993), but specific studies are required to document this in coastal habitats of NSW where translocated populations of $C$. destructor occur. Of the more than 40 indigenous freshwater fish species in coastal NSW (Allen et al., 2003), only four are listed as threatened:

-Eastern Freshwater Cod Maccullochella $i k e i$ is a large species (growing to $>65$ $\mathrm{cm})$ that displays parental guarding of egg masses (Allen et al., 2003; New South Wales Fisheries, 2004), and is unlikely to be susceptible to predation by $C$. destructor.

- Oxleyan Pigmy Perch Nannoperca oxleyana is a small species $(<7 \mathrm{~cm})$ that inhabits lowland creek and wallum habitats in northeastern NSW (Allen et al., 2003). At present, $C$. destructor is not known to 


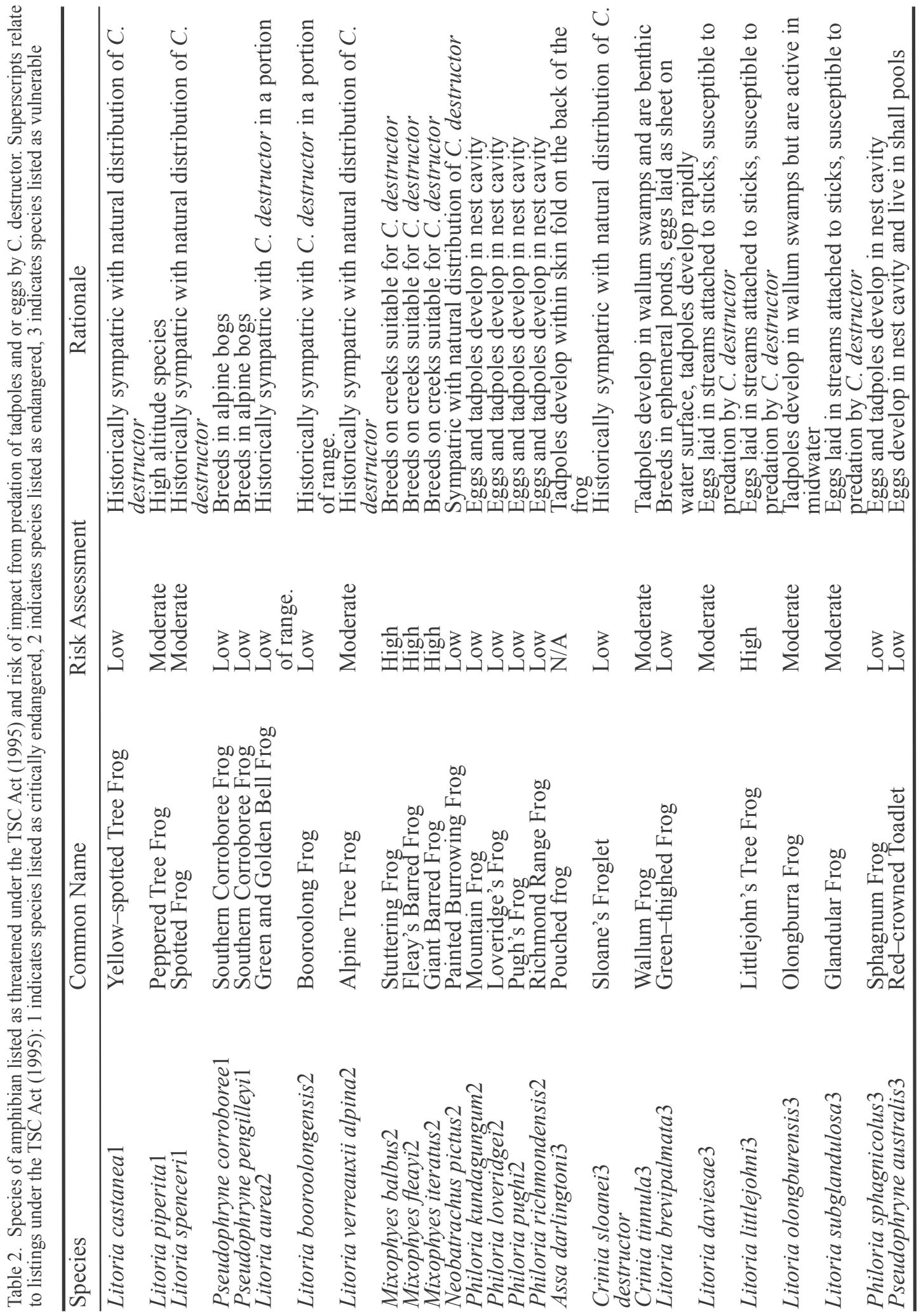


occur in $N$. oxleyana habitat, but this small fish would likely be susceptible to predation impacts should $C$. destructor become established within its range in the future.

- Macquarie Perch Macquaria australasica is a medium species $(\sim 45 \mathrm{~cm})$ with eggs that settle amongst the stones and gravel of the stream bed (Primary Industries Fishing and Aquaculture 2012); these eggs are considered to be susceptible by predation by $C$. destructor, which is known to occur within its range.

-Purple Spotted Gudgeon Mogurnda adspersa has experienced substantial declines in both its inland and coastal populations of NSW (West 2008). Although males guard the eggs, the small size of this fish $(12 \mathrm{~cm})$ would likely render both the eggs and the fish susceptible to predation impacts should C. destructor become established within the distribution of its coastal populations in future.

There are several coastal species of frog at potential risk from predation by $C$. destructor. The TSC Act 1995 (New South Wales Government, 2012) lists 29 frog species that are either critically endangered (5 spp.), endangered (12 spp) or vulnerable (12 spp.) to extinction (as at 8th July 2011). Of these species, two critically endangered, four endangered and five threatened species are considered at risk from impacts of $C$. destructor (Table 2). Four of these are considered at high risk of being impacted by $C$. destructor, as they breed in creeks (lotic) and lay their eggs in a single or several masses, hence making them more susceptible to being eaten than species that lay their eggs as dispersed, single units. Apart from Mixophyes fasciolatus, all other species of Barred frog, Mixophyes spp., in NSW are obligate stream breeders, whereas the Heath Frog is a species complex with populations in the Illawarra region of NSW mainly breeding in streams. These threatened species are considered to be most at risk from C. destructor because of their reproductive biology (lay eggs on clumps or masses) and the fact that they occur at relatively low altitude in habitat considered suitable for $C$. destructor.

Cherax destructor also impacts on species of frog that lay their eggs in still water. In general, ponds and dams that support large populations of $C$. destructor appear devoid of tadpoles (G. Daly pers. obs.). Species of frog that lay their eggs in masses, as opposed to those that lay single eggs, are considered at most risk of mortality associated with predation of eggs by $C$. destructor. Species that utilise ephemeral ponds and have a relatively short aquatic life phase are considered to have a lower risk than those that occur in more permanent habitats and/or have a longer aquatic life phase. Species that lay their eggs in the far upper reaches of creeks (seepages) such as members of the genus Pseudophryne and Philoria are also considered to have a low risk of predation by $C$. destructor, as these habitats are not favourable to yabbies. Species that occur in restricted habitats such as montane forests (e.g. Litoria piperita, $L$. spenceri, L. daviesae, and L. subglandulosa) are considered to have a moderate risk of impact, as Cherax destructor prefers warm temperatures and is less likely to proliferate in cold water in shaded environments (Withnall, 2000; Capinha \& Anastácio, 2011).

There is concern that $C$. destructor will also cause significant impacts on those species of frog that are currently not listed under the Threatened Species Section (1995) Act, and may cause additional species to be listed under that act. The greatest risk is considered to be for those species endemic to lowland habitats, lay eggs in masses and have a relatively slow aquatic phase. Species such as the Blue Mountains Tree Frog Litoria citropa, Haswell's Froglet Paracrinia haswelli and species within the Litoria phyllochroa complex may be at risk.

Predation impacts from translocated C. destructor are also relevant to aquatic invertebrates. The invertebrate fauna of coastal NSW is not as well known as other groups, but four species of dragonfly are currently listed as 'endangered' under State conservation legislation: Giant Dragonfly Petalura gigantea, Coastal Petaltail Petalura litorea, Adam's Emerald Dragonfly Archaeophya adamsi, and the Sydney Hawk Dragonfly Austrocordulia leonardi. 
In general, dragonfly nymphs are likely to be susceptible to predation by yabbies, although there is perhaps more chance of exposure for species that utilise surface water habitats ( $A$. adamsi and $A$. leonardi) than those that utilise bogs and swamps (Petalura spp.) (Department of Environment and Conservation, 2005a,b; Department of Primary Industries, 2005a,b). However, translocated yabbies could colonize swamp habitats, and observations of $C$. destructor within the vicinity of recorded sites for any of these threatened dragonfly species should be reported immediately.

One important consideration for the potential for damage by $C$. destructor on coastal ecosystems lies in the fact that the indigenous fauna may simply lack crucial recognition cues for this invading species. Furthermore, C. destructor also displays a generally high level of aggressive behaviour compared to many coastal crayfishes (J. Coughran pers. obs.). Gherardi et al. (2002) also found that invasive $C$. destructor in Western Australia make faster and more appropriate use of alarm odours than the indigenous $C$. tenuimanus.

Because $C$. destructor is a very robust animal with broad environmental tolerances it is capable of colonizing many aquatic habitats. The predation risk to endemic coastal fauna could therefore be wide reaching. In Western Australia, Bradsell et al. (2002) considered the introduced $C$. destructor more likely to present a threat to the critically endangered western swamp turtle, Pseudemydura umbrina, than three native species of Cherax. The turtle has a very restricted distribution and laboratory experiments indicated that $C$. destructor displayed higher aggression to turtle hatchlings than the indigenous C. quinquecarinatus. Cherax destructor is more a habitat generalist than all five Cherax endemic to Western Australia, and was considered more likely to successfully colonize the turtle habitat (Bradsell et al., 2002). This is comparable to the current situation in eastern NSW, where most native coastal crayfishes have specific habitat requirements and, consequently, restricted distributions (Merrick, 1993).

\section{Potential pathogen threats.}

Cherax destructor is known to carry a range of pathogens and parasites, including the microsporidian protozoan Thelohania sp., the fungus Saprolegnia sp. and the bacterium Pseudomonas sp. (Merrick, 1993). Currently there are no observations of transmission to endemic species in the coastal environments where $C$. destructor has been translocated, although the information base on existing pathogens and parasites of endemic coastal species is poor or absent.

\section{Potential impacts at the habitat and ecosys- tem level.}

Translocated C. destructor may cause significant habitat destruction that may adversely affect native flora and fauna in coastal catchments of NSW. In southern Australia where it has become established, it has destroyed macrophytes and caused siltation, and has thus been recognized as a threat to the native fish Dwarf Galaxias, Galaxiella pusilla (Threatened Species Section, 2006). Elsewhere in the world, translocated crayfish compete with fish for food, modify fish habitat by reducing shelter, spawning and nursery areas, and limit nutrient and food availability (Momot, 1995). For example, the invading Orconectes rusticus has not only significantly reduced macrophytes, but in so doing, may have significantly reduced fish populations (Capelli, 1982). The potential for adverse habitat impacts from $C$. destructor in coastal NSW should also be recognized, and could result from rapid population growth and/ or different behaviour of $C$. destructor in the receiving environment. For example, $C$. quadricarinatus display no burrowing ability in their natural environment, but when they became established in some overseas areas they were found to construct large U-shaped burrows that compromised stream integrity (Todd \& D'Andrea, 2003). The occurrence of $C$. destructor in all coastal catchments of NSW, and in essentially all habitat types, increases the potential for these impacts.

\section{General Remarks.}

Elsewhere in Australia where it has been introduced (e.g. Western Australia 
and Tasmania, where it has been listed as noxious), $C$. destructor has continued to expand its distribution and colonise new areas (Lynas et al., 2004; Beatty et al., 2005; Threatened Species Section, 2006). The situation appears to be the same in coastal NSW, where new populations are increasingly being recorded. The potential problems posed by this species require not just recognition, but co-ordinated research, management and education efforts (Coughran \& Furse, 2012), and it is imperative that this is initiated as soon as possible to minimize the potential for damage.

The coastal catchments of NSW have a relatively high biodiversity, with many species of indigenous crayfish and frog having restricted distributions. Until 2004 , no translocated populations of crayfish were known from coastal NSW, but within a short timeframe numerous populations of $C$. destructor and another species, the Redclaw C. quadricarinatus, have become widely reported (Coughran \& Leckie, 2007; Coughran et al., 2009; Leland et al., 2012). Taking action on this issue would therefore appear to be of imminent importance.

Acknowledgements. - We thank Rob McCormack for providing information regarding populations of $C$. destructor in eastern New South Wales.

\section{LITERATURE CITED}

Allen, G. R., Midgley, S. H., \& Allen, M., 2003. Field Guide to the Freshwater Fishes of Australia (Revised Edition). Western Australian Museum, Perth, Western Australia, 394 pp.

Austin, C. M., 1985. Introduction of the yabbie, Cherax destructor (Decapoda: Parastacidae) into southwestern Australia. Western Australian Naturalist, 16: 78-82.

Barnham, C., \& Barker, J., 2009. Fish Note 0082. Freshwater Fish of Victoria: Yabbies. Department of Primary Industries, Melbourne, Victoria, $3 \mathrm{pp}$.

Beatty, S., Morgan, D., \& Gill, H., 2005. Role of life history strategy in the colonisation of Western Australian aquatic systems by the introduced crayfish Cherax destructor
Clark, 1936. Hydrobiologia, 549: 219237.

Bradsell, P., Prince, J., Kuchling, G., \& Knott, B., 2002. Aggressive interactions between freshwater turtle, Chelodina oblonga, hatchlings and freshwater crayfish, Cherax spp.: implications for the conservation of the critically endangered western swamp turtle, Pseudemydura umbrina. Wildlife Research, 29: 295-301.

Butler, M. J. IV., \& Stein, R. A., 1985. An analysis of the mechanisms governing species replacements in crayfish. Oecologia, 66: 168-177.

Capelli, G. M., 1982. Displacement of northern Wisconsin crayfish by Orconectes rusticus (Girard). Limnology and Oceanography, 27: 741-745.

Capelli, G. M., \& Munjal, B. L., 1982. Aggressive interactions and resource competition in relation to species displacement among crayfish of the genus Orconectes. Journal of Crustacean Biology, 2: 486-492.

Capinha, C., \& Anastácio, P., 2011. Assessing the environmental requirements of invaders using ensembles of distribution models. Diversity and Distributions, 17: 13-24.

Coughran, J., \& Furse, J. M., 2010. An assessment of genus Euastacus (49 species) versus IUCN Red List criteria. Report prepared for the global species conservation assessment of crayfishes for the IUCN Red List of Threatened Species. The International Association of Astacology, 170 pp, Auburn, Alabama, USA. ISBN: 978-0-9805452-1-0.

Coughran, J., \& Furse, J. M., 2012. Conservation of Freshwater Crayfish in Australia. Special Issues of Crustacean Research: in Press.

Coughran, J., \& Leckie, S. R., 2007. Invasion of a New South Wales stream by the Tropical Crayfish, Cherax quadricarinatus (von Martens). In: Lunney, D., Eby, P., Hutchings, P., \& Burgin, S., Pest or Guest: the Zoology of Overabundance. Royal Zoological Society of New South Wales, Mosman, New South Wales, Australia. Pp. 40-46. ISBN 978-0-9803272-1-2. 
Coughran, J., McCormack, R. B., \& Daly, G., 2009. Translocation of the Yabby Cherax destructor into eastern drainages of New South Wales, Australia. Australian Zoologist, 35: 100-103.

Department of Environment and Conservation, 2005a. Coastal Petaltail - Profile. http://www.threatenedspecies. environment.nsw.gov.au/tsprofile/profile. aspx?id=20139, October 2011.

Department of Environment and Conservation, 2005b. Giant Dragonfly - Profile. http://www.threatenedspecies. environment.nsw.gov.au/tsprofile/profile. aspx?id=10600, October 2011.

Department of Primary Industries, 2005a. Adam's Emerald Dragonfly. http://pas. dpi.nsw.gov.au/Species/Species_Profile. aspx? SpeciesListingID=10, October 2011.

Department of Primary Industries, 2005b. Sydney Hawk Dragonfly. http://pas.dpi. nsw.gov.au/Species/Species_Profile. aspx? SpeciesListingID=9, October 2011.

Elvey, W., Richardson, A. M. M., \& Barmuta, L., 1996. Interactions between the introduced yabby, Cherax destructor, and the endemic crayfish Astacopsis franklinii, in Tasmanian streams. Freshwater Crayfish, 11: 349-363.

Furse, J. M., \& Coughran, J., 2011a. An assessment of the distribution, biology, threatening processes and conservation status of the freshwater crayfish, genus Euastacus (Decapoda: Parastacidae) in continental Australia. I. Biological background and current status. Crustaceana Monographs, 15: 241-252.

Furse, J. M., \& Coughran, J., 2011b. An assessment of the distribution, biology, threatening processes and conservation status of the freshwater crayfish, genus Euastacus (Decapoda: Parastacidae) in continental Australia. II. Threats, conservation assessments and key findings. Crustaceana Monographs, 15: 253-263.

Furse, J. M., \& Coughran, J., 2011c. An assessment of the distribution, biology, threatening processes and conservation status of the freshwater crayfish, genus Euastacus (Decapoda: Parastacidae) in continental Australia. III. Case studies and recommendations. Crustaceana Monographs, 15: 265-274.

Garvey, J. E., Stein, R. A., \& Thomas, H. M., 1994. Assessing how fish predation and interspecific prey competition influence a crayfish assemblage. Ecology, 75: 532 547.

Gherardi, F., Acquistapace, P., Hazlett, B. A., \& Whisson, G., 2002. Behavioural responses to alarm odours in indigenous and non-indigenous crayfish species: a case study from Western Australia. Marine and Freshwater Research, 53: 93-98.

Hawking, J. H., Smith, L. M., \& Le Busque, K., 2009. Identification and Ecology of Australian Freshwater Invertebrates. http://www.mdfrc.org.au/bugguide, January 2009.

Hill, A. M., \& Lodge, D. M., 1994. Dial changes in resource demand: competition and predation in species replacement among crayfishes. Ecology, 75: 21182126.

Horwitz, P. 1990. The translocation of freshwater crayfish in Australia: potential impact, the need for control and global relevance. Biological Conservation, 54: 291-305.

Horwitz, P., \& Knott, B., 1995. The distribution and spread of the yabby Cherax destructor complex in Australia: speculations, hypotheses and the need for research. Freshwater Crayfish, 10: 81-91.

IUCN, 2011. IUCN Red List of Threatened Species. Version 2011.1. http://www. iucnredlist.org, August 2011.

Lawrence, C., Morrissy, N., Bellanger, J., \& Cheng, Y.W., 1998. Final Report, FRDC Project 94/075: Enhancement of Yabby Production from Western Australian Farm Dams. Fisheries Research Report No. 112. Fisheries Research and Development Corporation, Fisheries Western Australia, Perth.

Lawrence, C. S., Morrissy, N. M., Vercoe, P.E., \& Williams, I. H., 2000. Hybridization in Australian freshwater crayfish - production of all-male progeny. Journal of the World Aquaculture Society, 31: 651-658.

Leland, J. C., Furse, J. M., \& Coughran, 
J., 2012. Further translocation of the Redclaw, Cherax quadricarinatus (Decapoda: Parastacidae), to Lake Ainsworth in northeastern New South Wales, Australia. Special Issues of Crustacean Research: submitted.

Lodge, D. M., Kratz, T. K., \& Capelli, G. M., 1986. Long-term dynamics of three crayfish species in Trout Lake, Wisconsin. Canadian Journal of Fisheries and Aquatic Sciences, 43: 993-998.

Lynas, J., Lindhjem, P., Storey, A., \& Knott, B., 2004. Is the Yabby, Cherax destructor (Parastacidae) in Western Australia an ecological threat? Freshwater Crayfish, 14: $37-44$.

Mather, M. E., \& Stein, R. A., 1993. Direct and indirect effects of fish predation on the replacement of a native crayfish by an invading congener. Canadian Journal of Fisheries and Aquatic Sciences, 50: 1279-1288.

McCormack, R. B., \& Coughran, J., 2011. Taxonomy, distribution and ecology of the Setose Yabby, Cherax setosus (Riek 1951). Crustacean Research, 40:1-11.

Merrick, J. R., 1993. Freshwater Crayfishes of New South Wales. Linnean Society of New South Wales, Sydney, 127 pp.

Momot, W. T., 1995. Redefining the role of crayfish in aquatic ecosystems. Reviews in Fisheries Science, 3: 33-63.

New South Wales Fisheries, 2004. Eastern (Freshwater) Cod (Maccullochella ikei) Recovery Plan. New South Wales Fisheries, Nelson Bay, New South Wales.

New South Wales Government, 2012. (TSC Threatened Species Conservation) Act (1995). http://www.legislation. nsw.gov.au/maintop/view/inforce/ act $+101+1995+\mathrm{cd}+0+\mathrm{N}$, January 2012

Olszewski, P., 1980. A Salute to the Humble Yabby. Angus and Robertson, Sydney, Australia.

Primary Industries Fishing and Aquaculture. 2012. Macquarie perch. http://pas.dpi. nsw.gov.au/Species/Species_Profile. aspx? SpeciesListingID=16.
Rabeni, C. F., 1985. Resource partitioning by stream-dwelling crayfish: the influence of body size. American Midland Naturalist, 113: 20-29.

Söderbäck, B., 1991. Interspecific dominance relationship and aggressive interactions in the freshwater crayfishes Astacus astacus (L.) and Pacifastacus leniusculus (Dana). Canadian Journal of Zoology, 69: 13211325.

Sokol, A., 1988. The Australian Yabby. In: Holdich, D. M., \& Lowery, R. S. (Eds.) Freshwater Crayfish: Biology, Management and Exploitation. CroomHelm Ltd., North Ryde, New South Wales.

Threatened Species Section, 2006. Recovery Plan: Tasmanian Galaxiidae 2006-2010. Department of Primary Industries, Water, Hobart, 85 pp.

Todd, S. R., \& D'Andrea, M., 2003. Alien Crayfish Invasion of Jamaican Rivers. Crayfish News, 25: 17-18.

West, R. 2008. Final Determination - Purple Spotted Gudgeon. FD35, Fisheries Scientific Committee, Port Stephens. http://www.dpi.nsw.gov.au/_data/assets/ pdf_file/0003/251337/FD35-purplespotted-gudgeon.pdf

Withnall, F., 2000. Biology of Yabbies (Cherax destructor). Department of Natural Resources and Environment, Victoria, $4 \mathrm{pp}$.

Addresses: (JC) Environmental Futures Centre, Griffith School of Environment, Gold Coast Campus, Griffith University, Queensland, Australia, 4222, and Outback Ecology, 1/73 Troy Terrace, Jolimont, Western Australia, 6014, Australia. (GD) Gaia Research Pty Ltd, PO Box 3109, North Nowra, NSW, 2541, Australia;

Email: (JC) jason.coughran@ outbackecology.com, (GD) gaiaresearch@ shoalhaven.net.au 